\title{
ASSESSMENT OF SERUM IRON, TIBC AND SERUM FERRITIN IN END STAGE RENAL DISEASE AND THE EFFECT OF HAEMODIALYSIS
}

\author{
By \\ Salama, O. S."; Lymon, N. E..*; Rizk, H. M.** \\ Hamed, M. A.** and Ramadan, F. A. ${ }^{* \star}$
}

From

Clinical Pathology* and Internal Medicine ${ }^{* *}$ Depts.

Mansoura Faculty of Medicine.

Received for Puplication : 1/2/1992

INTRODUCTION

Numerous hematological defects have been reported by many investigators in end stage renal disease. Such a bnormalities do affect most of the hematological parameters including erythroid series, granulocytic elements as well the hemostatic mechanism. Anemia stands as a hallmark among the numerous manifestations of chronic renal failure (CRF) representing the primary abnormality in such patients and adding more disabling symptoms than was previously appreciated (Eschabch \& Adamson, 1988). It is most invariably and its severity reflects the extent of renal impairment and may be correlated well with some serum biochemical abnor- malities (Erslev, 1970).

The pathophysiology of anemia in CRF has been attributed to multifactorial mechanisms including erythropoietin deficiency (Eschbach et al., 1987), shortened red cell survival (Blumberg \& Marti, 1972), retained inhibitors or toxic metabolites suppressing erythropoiesis (Fisher, 1980) and recurrent bleeding as a result of platelet dysfunction (Castaldi et al., 1966 and Jansen et al ., 1980). Superimposed on these possible mechanisms include the other causes of anemia peculiar to the dialysis patients that might aggravate the pre-existing anemia. Examples of these causes include the associated vitamin deMANSOURA MEDICAL JOURNAL 
ficiencies (Short et al., 1980), aluminium intoxication accumulating in the bones of haemodialysis patients that directly interfere with erythropoiesis in the marrow leading to microcytosis and disturbed haem synthesis (Trapp, 1983).

Iron deficiency is thought to be an eminent cause of anemia in CRF particularly in those undergoing periodic hemodialysis (Milman et al., 1980). Reports concerning serum $\mathrm{Fe}$ level in CRF are controversial. Some investigators reported raised serum $\mathrm{Fe}$ due to a concomitant chronic hemolysis, multiple blood transfusions. On the contrary, other workers reported that hypoferraemia is a constant stigma in CRF that may transfusion or even parentral iron therapy (Eschbach et al., 1987) necissate.

Serum ferritin level has been proven to be a useful indicator of iron stores in a lot of clinical situations as well as in patients on periodic hemodialysis (Finch et al., 1982). In certain pathological situations including uremicg on regular dialysis, serum $\mathrm{Fe}$ Vol. 22, No. 1 \& 2 Jan. \& April 1992 levels may not reflect the state of iron body stores (Moreb et al., 1983) i. e., iron levels could be high in the absence of iron overload, or exhibit normal values in the presence of depleted bone marrow stored iron. This dissociation in the normal relationship between serum iron and iron stores was referred by many workers to blood leucocyte contribution to serum ferritin levels in patients on maintainance hemodialysis (Millman et al., 1983). Therefore, serum ferritin may be of value in the diagnosis of iron lack in uremia (Kaltwasser, 1987). Moreover, assay of serum ferritin appears to be a reliable way to evaluate iron stores in hemodialysis patients (Moreb et al., 1983) because iron overload is a classical complication in such patients due to multiple transfusions besides iron therapy as a contributing factor (Halliday \& Powell, 1982). On the other hand, chronic blood loss is very frequent in CRF particularly in those on dialysis. Therefore, iron deficiency is a very common compliction in those patients. Hypoferremia develops within 6 to 24 months in dialysis patients even in the 
absence of overt bleeding (Kominami et al., 1971).

Improvement of anemia had been observed in some case under dialysis due to its favourable effect on erythropoiesis, better red cell survival and improvement of coagulation (Eschbach et al., 1977). Trials to use recombinant human erythropoietin (rHuEpo) have been effective in virtually all anemic hemodialysis patients. Moreover, a fall in serum ferritin has been observed after the use of rHuEpo (Eschbach et al., 1988).

\section{MATERIAL AND METHODS}

\section{Material:}

This study had been conducted on 51 patients with CRF, 9 of them before the start of any specific therapy and 42 on maintenance hemodialysis. Besides 6 healthy subjects ( 5 males and one female) as a reference group (Gpl) with a mean age of $47 \pm 10.9$ ys $(30-60)$. The patients were grouped into:

1. Group II: CRF before hemodialysis (HD), comprized 9 patients ( $7 \mathrm{M}$ and $2 \mathrm{~F}$ ), their age ranged between 37 to 60 ys (M: $48.8 \pm 9.8$ ).

2. Group III: CRF on hemodialysis included 42 cases ( $32 \mathrm{M}$ and $10 \mathrm{~F}$ ), their age ranged between 20 to 60 ys with a mean of 43.0 \pm 11.2 . According to the duration of hemodialysis, they were subdivided into:

i. Group IIIa: Hemodialysis less than one month, 10 patients ( $8 \mathrm{M}$ and $2 \mathrm{~F}$ ), their age ranged from 27 to 60 years with a mean of 34.7 ys.

ii. Group IIIb: Hemodialysis 1-6 months, 19 patients (15 $M$ and $4 \mathrm{~F}$ ), their age ranged between 25 to 57 ys (M: $42 \pm 8.1)$.

iii. Group IIIc: Hemodialysis more than 6 months, 13 patients ( $9 \mathrm{M}$ and $4 \mathrm{~F}$ ), with

MANSOURA MEDICAL JOURNAL 
an age range $20-60$ ys (M: 44.3土12.8).

All Gp III patients were on maintenance HD 2-3 sessions per week and any associated systemic diseases were excluded.

\section{Methods:}

After thorough clinical examination, the following laboratory investigations had been carried out for all subjects :

1. Complete hemogram including erythrocyte indices (Dacie \& Lewis, 1991).

\section{Biochemical tests: including}

a) Serum creatinine, urea, $\mathrm{Na}, \mathrm{K}$ and creatinine clearance using the standard methods.

b) Serum iron was determined by the colourimetric method described by Dreux (1977).

c) TIBC was determined by the colourimetric method of piccardi et al. (1972).

d) Serum ferritin was determined by monoclonal enzyme immunoassay (Forman \& Parke, 1980).

Vol. 22, No. 1 \& 2 Jan. \& April 1992
A non significant correlation had been found between the biochemical parameters and iron data within group II. On the other hand, a negative correlation had been observed between serum creatinine and serum iron while a positive correlation could be noticed between s. creatinine and TIBC. Meanwhile, a non significant correlation had been detected between $S$. creatinine and $S$. ferritin. As regards creatinine clearance, a non significant correlation had been noticed with serum $\mathrm{Fe}$, TIBC and $S$. ferritin in this group. When the duration of hemodialysis was considered, a non significant correlation had been found between the studied parameters within the subgroups apart from a negative correlation between creatinine clearance and S. ferritin in Gp IIIb and also a negative significant correlation between $\mathrm{S}$. creatinine and S. ferritin in Gp IIIc.

\section{DISCUSSION}

Anemia seems to be a frequent hematological abnormality in uremic patients particularly those undergoing periodic hemodialysis (Eschbach et al., 1987). Recently, there have been 
numerous significant advances in the data about the pathophysiology and hence the management of anemia in CRF (Fisher, 1980) because of the unique relationship between the kidney and red cell production via erythropoietin.

Iron deficiency seems to be one of the contributing factors in the development of anemia in CRF (Anagoston et al., 1981), while it is the commonest cause of anemia in those undergoing periodic hemodialysis (Milman et al., 1980). At the same time serum ferritin level has been proven to be a useful indicator of iron stores in a lot of clinical conditions as well as in patients on hemodialysis, while the routinely estimated erythrocyte indices are unreliable to underline the actual iron status (Finch, 1982 and Aljama et al., 1987). On the otherhand, blood transfusion and parentral iron are frequently adminstered to CRF patients particulary those on dialysis aiming at correction of anemia. Accordingly, this work is an attempt to evaluate the relevance of blood indices, serum iron and serum ferritin in such patients.
In this study uremic patients showed a highly significant reduction in hemoglobin level, red cell count and PCV. Meanwhile, the erythrocyte indices revealed that the existing anemia was mostly hypochromic and microcytic as well. The pathogenesis of this anemia in CRF has been ascribed to be multifactorial namely erythropoiotin deficiency (Eschbach et al., 1987), iron deficiency due frequent bleeding episodes (Castaldi et al., 1966). Beside these major factors, shortened red cell survival as a result of the toxic melieu proved by Blumberg \& Marti (1972), and the inhibitory effect of the retained metabolites on erythropoiesis (Fisher, 1980). In our cases, the degree of iron deficiency was more aggravated in haemodialysis group. This could be attributed to a further progressive iron loss during dialysis e.g., accidental leak from cannula, fistula or through the dialyzer membrane in addition to frequent blood sampling, reduced iron intake because of protein restriction, increased occult blood loss and the unavoidable retention of some blood in dialysis machine and erythrocyte destruction in the extracorporeal

MANSOURA MEDICAL JOURNAL 
circulation (Longenecker, $1974 \mathrm{Re}$ - Therefore, the PCV was not normalcently, microcytic hypochromic anemia has been observed in aluminium intoxicated dialysis cases (Short et al., 1980 and O Hare Nurnoghan, 1982). They attributed this variety of anemia to a toxic aluminium effect on the erythropoietic function. ized after dialysis. The same findings were reported by Stephen \& Korbet (1989). Although, erythrocyte indices point to the presence of iron deficiency, yet they do not differentiate patients with depleted iron store.

In this work, a highly significant re-

On the otherhand, a relative improvement in PCV had been observed after dialysis in the studied cases. This may be referred to reduction of excess fluids and hence diminighed plasma volume, clearance of uremic toxins, thus improving erythropoietin efficiency and red cell survival time, thereby increase red cell mass. Koch et al. (1974) reported that increasing dialysis time frequently results in a significant improvement of anemia in such patients. Even though, this work revealed that the PCV values had not changed significantly whatever the duration of dialysis.

This can be attributed to the inability of the damaged kidneys to produce an adequate level of Epo or that the uremic toxins were not totally cleared.

duction in both serum $\mathrm{Fe}$ and serum ferritin was observed in both predialysis as well as in dialysis group as compared to the control. This has been found in agreement with the findings of Finch (1982) and Blumberg et al. (1983). Hussein and his co-workers (1975) concluded that serum ferritin was correlated with the body iron stores estimated by grading the bone marrow iron and so, serum ferrtitin is an ideal method for monitoring the iron status in uremics and hemodialysis patients. The significantly reduced ferritin level encountered in this study in dialysis was not affected by the variability of duration of dialysis. This can be considered to be an indicator of a marked iron store depletion in such cases which might be aggravated by dialysis. Many authors reported Vol. 22, No. 1 \& 2 Jan. \& April 1992 
also a reduction in serum ferritin level which was parallel to bone marrow iron stores (Bell et al., 1980). The same forementioned factors responsible for reduction of serum iron could be indulged in the diminution of serum ferritin. On the other hand, other authors reported that serum ferritin levels in patients undergoing regular haemodialysis showed a dissociation from bone marrow iron stores (Salti et al., 1991), and the estimation of bone marrow iron seems to be the most direct approach for clinical evaluation of iron status, while Brunati et al. (1987) proposed that red cell ferritin assay is a more sensitive method but it is sophisticated procedure. On the contrary, a conflicting results had been reported by Halliday \& Powell (1982) who reported that an iron overload state was a classical complication in their hemodialysis series. They attributed that to multiple blood transfusions and uncontrolled iron administration.

\section{SUMMARY AND CONCLUSIONS}

Because of the variability in the pathogenesis of anemia in CRF and the accepted usage of iron supplementation, we attempted to evaluate the importance of blood indices, serum iron and serum ferritin in such conditions as serum ferritin is generally considered as the best indirect index of body iron stores. This work included 52 uremic patients besides 6 control subjects. The patients were grouped into predialysis and dialysis groups. The later were further subdivided into 3 subgroups according to the duration of dialysis. Biochemical tests, complete hemogram including erythrocyte indices, serum iron, TIBC and serum ferritin had been carried out for all subjects.

All uremic patients - irrespective of dialysis - were suffering from microcytic hypochromic anemia with marked iron deficiency and low serum ferritin. There was a statigtically insignificant change of iron status in dialysis groups irrespective the variable duration of dialysis. We came to the conclusion that evaluation of serum ferritin is essential to assess the body iron stores and to evaluate the indication of iron supplementation in CRF and 
dialysis patients because the hemato- should be cautiously used after inveslogical indices alone can not point to tigating the iron status in such pathe actual iron stores. Reevaluation of tients. An extenson of this work could the adequacy of hemodialysis proce- be suggested to investigate the erythdure can be garanteed with the im- rocyte ferritin, bone marrow iron in provement of iron parameters. Moreo- CRF and a trial to use RHuEpo in ver, iron supplementation in CRF those patients. 
Salama, O. S. et al...

Table (I) : Serum Iron, TIBC and serum ferritin in the studied groups.

\begin{tabular}{|c|c|c|c|c|c|c|}
\hline & \multicolumn{2}{|c|}{$\begin{array}{l}\text { S. Iron } \\
\text { ug / dl }\end{array}$} & \multicolumn{2}{|c|}{$\begin{array}{c}\text { TIBC } \\
\mathrm{ug} / \mathrm{dl}\end{array}$} & \multicolumn{2}{|c|}{$\begin{array}{l}\text { S. Ferritin } \\
\text { ug / dl }\end{array}$} \\
\hline & $M$ & $\pm S D$ & $M$ & $\pm S D$ & $M$ & $\pm S D$ \\
\hline $\begin{array}{l}\text { Group I } \\
(n=9)\end{array}$ & 90.8 & 11.8 & 336.5 & 63.5 & 170.3 & 57.3 \\
\hline $\begin{array}{l}\text { Group II } \\
(n=9)\end{array}$ & 75.2 & 11.5 & 396.4 & 69.5 & 59.8 & 12.5 \\
\hline $\begin{array}{l}\text { Group III } \\
(n=42)\end{array}$ & 51.0 & 19.8 & 19.8 & 100.7 & 57.1 & 20.5 \\
\hline$P_{1}$ & \multicolumn{2}{|c|}{$<0.01$} & \multicolumn{2}{|c|}{$<0.05$} & \multicolumn{2}{|c|}{$<0.001$} \\
\hline$P_{2}$ & \multicolumn{2}{|c|}{$<0.001$} & \multicolumn{2}{|c|}{$<0.01$} & \multicolumn{2}{|c|}{$<0.001$} \\
\hline$P_{3}$ & \multicolumn{2}{|c|}{$<0.001$} & \multicolumn{2}{|c|}{$>0.05$} & \multicolumn{2}{|c|}{$>0.05$} \\
\hline
\end{tabular}

$P_{1}$ : GP \| versus GP ।.

$P_{2}$ : GP III versus GPI.

$P_{3}: G P \|$ versus $G P \|$.

Table (2) : Serum Iron. TIBC and serum ferritin in CRF patients under

\begin{tabular}{|c|c|c|c|c|c|c|}
\hline & \multicolumn{2}{|c|}{$\begin{array}{l}\text { S. Iron } \\
\text { ug / dl }\end{array}$} & \multicolumn{2}{|c|}{$\begin{array}{c}\mathrm{TIBC} \\
\mathrm{ug} / \mathrm{dl}\end{array}$} & \multicolumn{2}{|c|}{$\begin{array}{l}\text { S. Ferritin } \\
u g / \mathrm{ml}\end{array}$} \\
\hline & $M$ & $\pm S D$ & $M$ & $\pm S D$ & $M$ & $\pm S O$ \\
\hline $\begin{array}{l}\text { Group IIIa } \\
(n=10)\end{array}$ & 73.5 & 6.9 & 398.0 & 67.4 & 57.2 & 20.3 \\
\hline $\begin{array}{l}\text { Group IIIb } \\
(n=19)\end{array}$ & 40.1 & 17.4 & 489.5 & 101.1 & 54.6 & 21.9 \\
\hline $\begin{array}{l}\text { Group IIIC } \\
(n=13)\end{array}$ & 49.7 & 15.3 & 426.0 & 102.8 & 53.3 & 19.4 \\
\hline$P_{1}^{\prime}$ & \multicolumn{2}{|c|}{$<0.001$} & \multicolumn{2}{|c|}{$>0.01$} & \multicolumn{2}{|c|}{$<0.05$} \\
\hline$P_{2}^{\prime}$ & \multicolumn{2}{|c|}{$<0.001$} & \multicolumn{2}{|c|}{$<0.05$} & \multicolumn{2}{|c|}{$>0.05$} \\
\hline $\mathrm{P}_{3}$ & \multicolumn{2}{|c|}{$<0.05$} & \multicolumn{2}{|c|}{$>0.05$} & \multicolumn{2}{|c|}{$>0.05$} \\
\hline
\end{tabular}

n : number of cases.

$P_{1}$ : GP II versus GP I.

$P_{2}: G P$ III versus GPI.

$P_{3}$ : GP $\|$ versus $G P \|$. 
Table (3) : Correlation coefficient between iron parameters and biochemical parameters in the studied groups.

\begin{tabular}{|c|c|c|c|c|c|}
\hline & & S. Iron & TIBC & S. Ferritin & $\begin{array}{r}\text { Critical } \\
\text { value }\end{array}$ \\
\hline \multirow[t]{2}{*}{ Group I } & S. Creat. & 0.27 & -0.33 & -0.44 & $+/-0.58$ \\
\hline & Creat. Cl. & 0.18 & -0.24 & 0.22 & \\
\hline \multirow[t]{2}{*}{ Group II } & S. Creat. & -0.32 & 0.29 & -0.06 & $+/-0.25$ \\
\hline & Creat. Cl. & -0.19 & 0.25 & -0.09 & \\
\hline \multirow[t]{2}{*}{ Group IIla } & S. Creat. & 0.09 & -0.26 & 0.03 & $+/-0.55$ \\
\hline & Creat. $\mathrm{Cl}$. & 0.08 & 0.34 & 0.18 & \\
\hline \multirow[t]{2}{*}{ Group illb } & S. Creat. & 0.05 & 0.11 & 0.07 & $+1-0.44$ \\
\hline & Creat. Cl. & -0.14 & -0.24 & -0.46 & \\
\hline \multirow[t]{2}{*}{ Group IIIc } & S. Creat. & -0.43 & 0.29 & -0.49 & $+/-0.47$ \\
\hline & Creat. Cl. & -0.43 & -0.11 & -0.39 & \\
\hline
\end{tabular}

Vol. 22, No. 1 \& 2 Jan. \& April 1992 


\section{RFFERENCES}

Aljama, P.; Ward, M.; Pieridis, A.;

Eastham, E. and Ellis, $\mathrm{H}$. (1987) : Clin. Nephrol. 10 : 101-114.

Anagnostou, A.; Fried, W. and Kurtzman, N. (1981) : The kidney, 2 nd ed. 2184-2212.

Bell, J. D.; Kinacaid, W. R. and Morgan, R. G. (1980): Kidney. Int., 17 : 237-241.

Blumberg, A. and Marti, H. (1972): Proc. Eur., Dial. Transpiant. Assoc., 9 : 91-95.

Brunati, C.; Piperno, A. and Civati, G. (1987): Roma, Acta Medica, 361-364.

Castaldi, P.; Rozenberg, M. and Stewart, J. (1966) : Lancet, 2 : Fisher, J. W. (1980) : Nephron, 25 : 66-69.

Dacie, J. and Lewis, S. (1991): Prac- Forman, D. T. and Parke, S. I. tical Hematol. 6th ed., 8 , 249.
Druez, C. (1977) : Ann. Biol. Clin., 35 :275.

Erslev, A. J. (1970) : Archs. Intern. Med., $126: 774-780$.

Eschbach, J. W.; Kron, D. and Finch, C. A. (1977) : J. Lab. Clin. Med., $89: 823$.

Eschbach, J. W. : Egrie, J. C.; Downing, M. R.; Brown, J. K. and Admson, J. W. (1987) : Clinical Trial N. Eng. J. Med., 316: 73-80. W. (1988) : Am. J. Kidney Dis 203-9. Med., $307:$ 1702-1704. 106-111. (1980): Ann. Clin. Lab. Sci. $10: 345$.
Eschbach, J. W and Adamson, J.

Finch, C. A. (1982) : New Eng. J. 
Halliday, J. W. and Powell, L. K. Milman, N.; Christensen, T. E. and (1982) : Semin. Hematol., Standberg, N. S. (1980): 19: $42-53$. Acta Med. Scand., 207 : 201-205.

Hussein, S.; Perieto, J.; O'Shea, M.; Hoffbrand, A. V.; Baillod, O'Hare, J. A. and Nurnoghan, D. J. A. and Moorhead, J. W. (1975) : Br. Med. J., $1: 456-$ 458.

Jansen, P. A.; Jubeliere, S. J.; Weinstein, M. J. and Deykin, A. (1980) : N. Eng. Med., 203 : 1318-1322.

Kaltwasser, J. P. (1987) : Follia Hematol., $114: 319-337$. (1982) : New Eng. J. Med., 306,654 .

Piccardi, G.; Nyssen, M. and Dorche, J. (1972): J. clin. Chim. Acta., $40: 219$.

Salti, N. N.; Jabre, F.; Saab, G.; Daouk, M. and Salem, Z. (1991) : Nephron, 57 : 144148.

Koch, K. M.; Patyna, W. D.; Shal- Short, A.; Winney, R. and Rabson, don, S. and Wener, E. (1974) : Nephron 12 : 40519.

J. (1980) : Pro. Eur. Dial. Transplant. Assoc., 17 : 226233.

Kominami, N.; Lowrie, E. G.; lahez, L. E. and Sharkem, A. Stephen, M. and Korbet, M. D. (1971) : J. Lab. Clin. Med., 78,524 . (1989): Nephrology, $9: 915$.

Trapp, G. A. (1983) : Lif. Sci., 33 : 311.

Longencker, R. E.; Goffinet, J. P. and Hendler, E. D. (1974) : Trans. Am. Soc. Atif. Int. Organs, $20: 135-141$.

Vol. 22, No. 1 \& 2 Jan. \& April 1992 


\section{تقييم نسبة الحديد بالمصل وكفا ءة الارتباط بالحديد ونسبة الفريتين} بالمصل فى مرضى الفشل الكلوى وتأثير عملية الغسيل الدموى بلدي

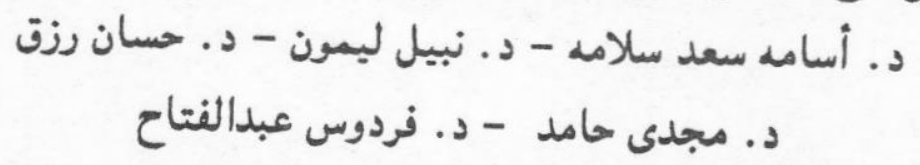

الملخص والاستنتاجات : - المات

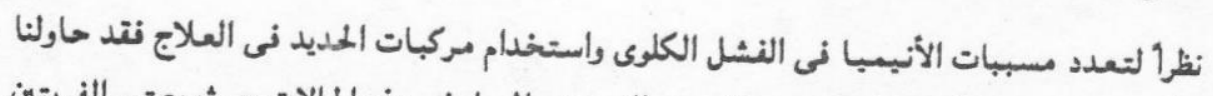

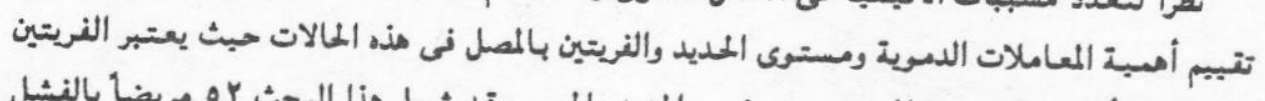

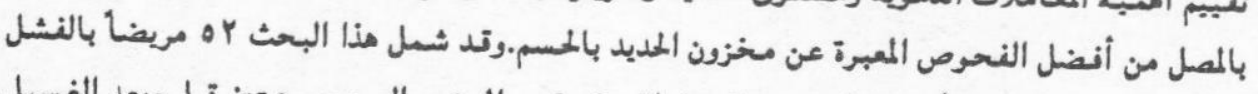

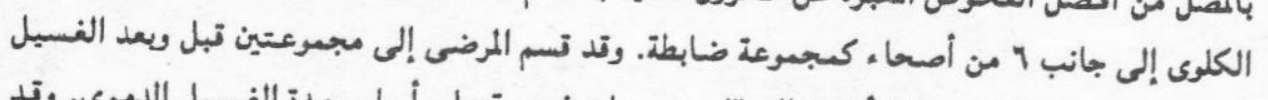

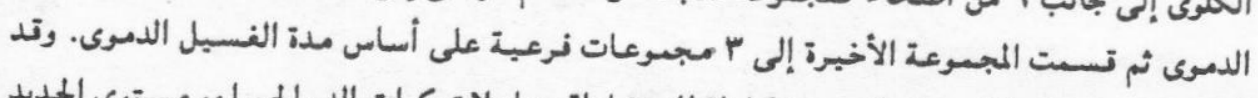

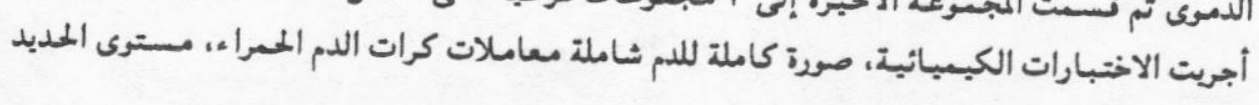
والنريتين بالمصل.

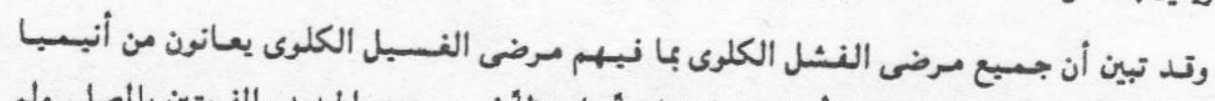

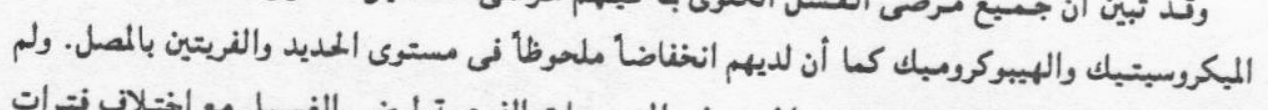

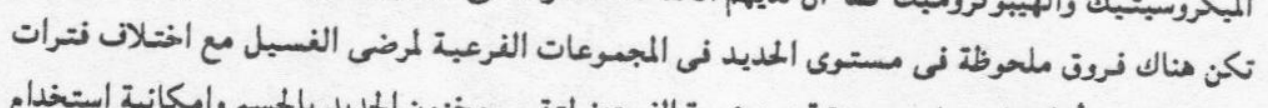

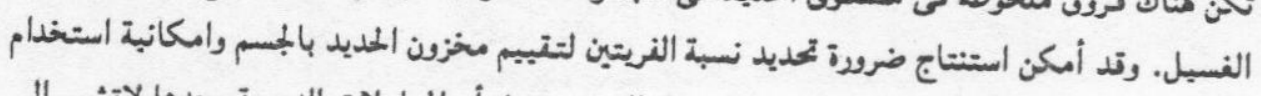

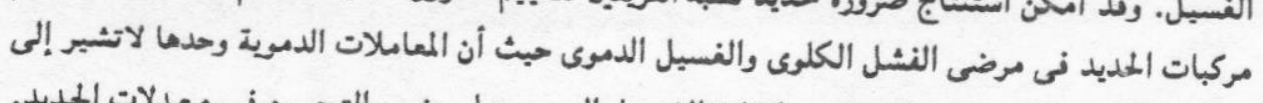

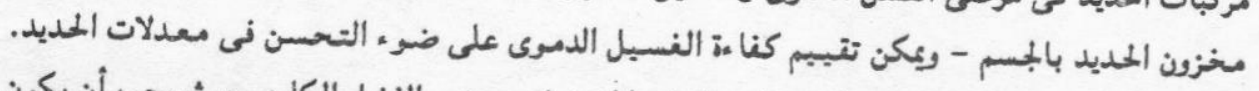

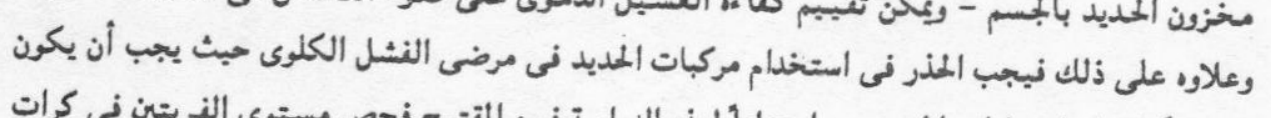

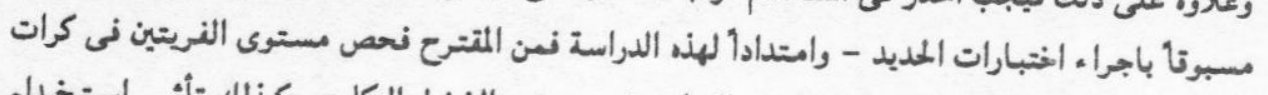

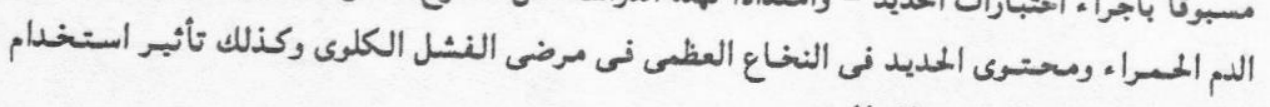

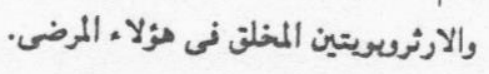


